\title{
Do industrial and geographic diversifications have different effects on earnings management? Evidence from UK Mergers and Acquisitions
}

\author{
Camelia Vasilescu $^{\mathrm{a}} *$ and Yuval Millo ${ }^{\mathrm{b}}$
}

${ }^{a}$ University of Leicester School of Management, University Road, Leicester, LE1 7RH, United Kingdom, e-mail: cv56@le.ac.uk
${ }^{b}$ University of Leicester School of Management, University Road, Leicester, LE1 7RH, United Kingdom,e-mail: ym95@le.ac.uk

\begin{abstract}
This paper examines whether corporate diversification has an impact on accruals earnings management by UK targets in M\&As. Following prior research (Jiraporn et al., 2008; El Mehdi and Seboui, 2011), we explicitly distinguish between industrial and geographic diversification. These two dimensions of diversification differ in terms of their degree of information asymmetry, while in industrially diversified firms the accruals at the business segment level tend to offset each other, geographically diversified firms seem to be subject to higher information asymmetry. Using a sample of 229 UK publicly listed targets and employing cross-sectional accrual models and a panel regression framework, we find that industrial diversification mitigates earnings management by UK targets prior to M\&As. The results of our study also show that a combination of industrial and geographic diversification is associated with a lesser degree of earnings management, which is consistent with those reported by Jiraporn et al. (2008) and El Mehdi and Seboui (2011) for US firms. However, our evidence suggests that geographic diversification is associated with a higher degree of earnings management, however the results are not statistically significant.
\end{abstract}

Keywords: Corporate industrial diversification and geographic diversification, Information asymmetry hypothesis, Accruals earnings management, Mergers and acquisitions.

* Corresponding author. e-mail: cv56@le.ac.uk 


\section{Introduction}

Both the popular press and academics suggest that industrially and geographically diversified firms are subject to increased information asymmetry and agency costs and as a result corporate diversification is a value-destroying strategy (Lang and Stulz, 1994; Berger and Ofek, 1995; Denis et al., 1997). Consequently, the literature indicates that the degree of earnings management by targets is conditional upon its degree of organisational complexity, such as the level of industrial and geographic diversification. The extent of opportunistic earnings management is likely to be higher the greater the level of information asymmetry (Richardson, 2000). Nevertheless, in spite of interest in the two types of diversification, there is little research about the potentially different impact that industrial and geographic diversification may have on earnings management. This research aims to address this point.

Research documents a value discount associated with industrial diversification and argues that this supports information asymmetry hypothesis (Lang and Stulz, 1994; Berger and Ofek, 1995; Denis et al., 1997), whereby industrially diversified firms have a higher degree of information asymmetry due to increased complexity of operations and management structure (Nam et al., 2006) and the ownership structure of the firms (Denis et al., 1997). In addition, industrially diversified firms' earnings reports are more difficult to scrutinize and require more resources and expertise for investors and analysts (Thomas, 2002). However, more recent research claims that greater industrial diversification is not associated with increased information asymmetry (Thomas, 2002; Jiraporn et al., 2008; El Mehdi and Seboui, 2011).

Geographically diversified firms are larger and have more complex organisational structures than domestic firms, which leads to higher costs of monitoring managerial decision (Bodnar et al., 1997) and makes coordinating corporate policies more difficult (Denis et al., 2002). Additionally, Duru and Reeb (2002) argue that geographically diversified companies are less transparent which poses difficulties for financial analysts to analyse these companies' performance and assess their value.

The inconclusive evidence about the impact of industrial and geographical diversification strategies when examined separately is also repeated in the literature that compares the two strategies. Gande et al. (2009) document that industrial diversification and geographic diversification are inherently different, and claim that the benefits of geographic diversification (driven by both real dimensions and financial dimensions) are higher than those of industrial diversification (driven only by real dimensions). Examining a sample of 
US firms, El Mehdi and Seboui (2011) find that geographic diversification increases earnings management, but that industrial diversification mitigates it.

Further motivations for our study come from methodological reasons. The current literature is focused mainly on US data (e.g., Easterwood, 1997; Erickson and Wang, 1999; Shen, 2005; Anilowski et al., 2014) and the conclusions are limited to US companies because the results have been gained by analysing samples consisting exclusively or almost exclusively US companies. Whether they are generalizable beyond the US context is an open question. In addition, little is known about whether the organisational structure of the targets may affect the targets' discretionary accruals prior to a transaction.

Prior studies have investigated whether targets attempt to manipulate reported earnings prior to M\&As, which offer direct opportunities for managing earnings to boost the stock price and implicitly gain a higher deal premium and value. M\&As provide a good setting in which to examine whether corporate diversification affects earnings management since takeovers may provide a strong incentive to targets' managers to inflate reported earnings (e.g., Moeller et al., 2004; Antoniou et al., 2008). Moreover, targets' managers may agree to merge for private benefits, such as stock and option appreciation, special cash bonuses (side payments), increased golden parachutes, CEO position or board membership in the merged company (e.g., Hartzell et al., 2004). In addition, the costs of detection of earnings manipulation are seemingly lower after the deal takes place as there is no observable reversal of accruals, which in normal circumstances will lower the reported earnings of the future periods (e.g., Dechow, 1994; Kasznik, 1999; Barton and Simko, 2002; Choy, 2012) and have negative consequences on stock return (e.g., Rangan, 1998; Teoh et al., 1998).

In this paper, which aims to add clarity to the issue of whether the strategies of industrial and geographic diversification are related to increased levels of earnings management, we compare the occurrences of accruals earnings management in companies that are industrially and geographically against focused firms. We explicitly distinguish between industrial and geographic diversification. Using a sample of 229 UK publicly listed targets, we first estimate discretionary accruals by employing two widely-used crosssectional accruals models, namely the cross-sectional modified-Jones model and the performance-adjusted model. Then, we investigate the relationship between earnings management and industrial and geographic diversification by using a panel data framework. Our empirical evidence shows that industrial diversification mitigates earnings management which is in line with Jiraporn et al. (2008) and El Mehdi and Seboui (2011) who argue that industrial diversification decreases earnings management by US firms. We also find that a 
combination of industrial and geographic diversification alleviates earnings management and geographic diversification is associated with a higher degree of earnings management.

The remainder of the paper is organised as follows: section 2 discusses the literature review and develops the hypotheses, section 3 presents the research methods, section 4 reports the data and empirical results, and section 5 concludes.

\section{Literature Review and Hypotheses Development}

\subsection{Earnings Management by targets}

There are strong incentives for targets' managers to manipulate reported earnings upward prior to a takeover in an attempt to boost the stock price. They may be motivated to inflate reported earnings to increase the deal premium for shareholders and there is clear evidence that targets' shareholders make substantial gains in takeovers (Moeller et al., 2004; Antoniou et al., 2008). Targets' managers may also agree to merge for personal reasons, such as retirement or illiquid stock ownership, and they can negotiate special bonuses or increased golden parachutes (Hartzell et al., 2004), as well as generous severance pay or top positions within the merged company (Shleifer and Vishny, 2003). Finally, targets may also attempt to manage reported earnings upward prior to a takeover in response to earnings manipulation by the acquirers (Easterwood, 1997). ${ }^{1}$ Another argument in favour of earnings management by targets refers to the expected finite short life of the company at the time of a deal. Most targets disappear or are incorporated into a newly merged company after takeover. Debatably, the motivation for earnings manipulation in these companies is stronger, the managers will try to increase the bottom line at any expense to boost the stock price prior to a transaction, as opposed to managers of companies with indefinite life whose main goal is to maximize shareholders' wealth long-term.

However, there are high costs associated with accruals earnings manipulation. These are primarily due to auditors' and regulators' scrutiny and the risk of litigation (e.g., Graham et al., 2005; Zang, 2011). In the UK, even though the costs associated with auditors are significant (Beattie et al., 2003) ${ }^{2}$, this environment is not perceived to be as highly litigious as

\footnotetext{
${ }^{1}$ Under the takeover defence hypothesis developed by Easterwood (1997), if the acquirer overstates prior earnings, then the target can anticipate the degree of earnings manipulation and adjust upward its reported earnings in order to gain a higher deal premium from the acquirer.

${ }^{2}$ Beattie et al. (2003) argue that the costs associated with auditors in the UK are significant due to the high quality of audits provided by Big-X audit firms. They document that the largest audit firms (or Big-X audit
} 
the US (Seetharaman et al., 2002). Specific to the M\&A context, the costs of detection of earnings manipulation after the deal are seemingly lower as there is no observed reversal of accruals, which in normal circumstances will lower the reported earnings of the future periods (e.g., Dechow, 1994; Kasznik, 1999; Barton and Simko, 2002; Choy, 2012) and have negative consequences on stock return (e.g., Rangan, 1998; Teoh et al., 1998). This suggests that the costs of detection of earnings management within targets might be lower than those faced by other companies during normal business activities.

The timing argument, that is whether or not the target is aware of the potential bid until the acquirer initiates negotiations and has the time necessary to manipulate earnings to increase the stock price before the transaction, has been discussed in literature. Erickson and Wang (1999) and Skaife and Wangerin (2013) argue that although targets have incentives to manipulate earnings upward prior to a takeover, they have difficulty anticipating if and when a bid from an acquirer will be received. However, sometimes the initiative of making itself available for takeover comes straight from the targets. Boone and Mulherin (2007) find that half of the targets were sold via auction in which the target privately contacted potential buyers prior to a public announcement. Shen (2005) and Anagnostopoulou and Tsekrekos (2012) examine earnings management by US "soliciting" and "seeking buyer" targets and find that they act as initiators of M\&A transactions for a number of reasons, such as leverage, undervaluation, growth, strategy-related or distress. This evidence shows the takeover process seems to start long before the official date announcement and unofficial meetings between potential partners are usually launched in advance. Thus, the targets are likely to become aware of a potential takeover long before the transaction offers are made public by the acquirers, which may give the managers the opportunity and time to manipulate earnings.

The evidence provided by prior empirical studies on earnings management by targets in M\&As is mixed and has been provided mainly by US studies. While Easterwood (1997) and Erickson and Wang (1999) find that targets attempt to manipulate reported earnings upward in hostile takeovers and stock-for-stock deals respectively, Eddey and Taylor (1999) provide unclear evidence that earnings management is used to support target directors' recommendations on bids within Australia. Consistent with their findings, Anilowski et al. (2014) argue that targets in auction deals are more likely to use income-increasing earnings management to boost the stock price prior to a takeover. In contrast, Shen (2005) and Anagnostopoulou and Tsekrekos (2012) examine US soliciting targets and "seeking buyer"

firms) held over $90 \%$ of the UK market in 2002 and audited all the FTSE 100 companies and most other listed companies. 
firms and find that these specific targets engage in income-decreasing accruals earnings management to the deal. ${ }^{3}$ Anagnostopoulou and Tsekrekos (2013) document that the incomedecreasing earnings management behaviour previously reported in the US is also confirmed for the UK and Italy and their results also reveal significantly positive abnormal returns for UK “seeking buyer" firms.

\subsection{Industrial diversification, geographic diversification and information asymmetry}

Prior literature suggests that the degree of opportunistic earnings management should increase with the level of information asymmetry (Dye, 1988; Trueman and Titman, 1988). Richardson (2000) provides evidence that the greater the information asymmetry, the more likely the firm is to manage accruals and earnings.

Corporate industrial diversification is generally viewed as a value-reducing strategy due to agency costs and information asymmetry (Lang and Stulz, 1994; Berger and Ofek, 1995; Denis et al., 1997). The information asymmetry hypothesis claims that firms that operate in many industries tend to have more sophisticated organisational structure to control the operations of the firm. For example, the accounting information of an industrially diversified firm is less value-relevant to outsiders than that of a focused firm due to the aggregate nature of the industrially diversified firm's accounting reports (Lim et al., 2008). It is regarded to be more difficult to scrutinize the industrially diversified firm's earnings reports and to require more resources and expertise for investors and analysts (Thomas, 2002). Lim et al. (2008) find evidence that industrially diversified SEO firms are more aggressive in manipulating earnings than focused companies which suggests that information asymmetry problems are more severe in these firms. As a result, there is more information asymmetry between managers and shareholders and industrially diversified firms are potentially less transparent than focused firms. Therefore, managers of industrially diversified firms may exploit the additional information asymmetry and engage in more earnings management than those of focused firms. In addition, Denis et al. (2002) argue that managers may benefit from industrial diversification through increased power and prestige, and may have better compensation arrangements or risk reduction.

However, industrially diversified firms could ease the information asymmetry between the managers and investors by allocating resources more efficiently thorough

\footnotetext{
${ }^{3}$ Shen (2005) and Anagnostopoulou and Tsekrekos (2012) claim that soliciting targets make income-decreasing accruals choices to 'clean-up' their financial statements before a takeover which leads to an increased probability to secure a takeover.
} 
internal capital markets, exploiting economies of scale/scope, and diversifying firm risks (Lewellen, 1971; Gertner et al., 1994; Stein, 1997). Managers of industrially diversified firms can also mitigate the information asymmetry by credibly increasing segment disclosure and signalling more information to the public and the shareholders (Subramanyam, 1996). The literature on corporate industrial diversification and insider trading provides evidence that corporate directors (insiders) purchase more of their industrially diversified firms in the open market when diversification is high, which suggests that industrial diversification is a valueincreasing strategy and insider trading may help mitigate the information asymmetry between managers and investors (Ataullah et al., 2014).

More recent research on effects of industrial diversification questions the occurrence of additional agency cost problems in industrially diversified firms (Jiraporn et al., 2008; El Mehdi and Seboui, 2011) and finds that greater industrial diversification is not associated with increased information asymmetry (Thomas, 2002). In this respect, Jiraporn et al. (2008) claim that industrial diversification helps to mitigate discretionary accruals by $1.8 \%$ and their evidence rejects the information asymmetry hypothesis. They argue that industrially diversified firms derive their cash flows from diverse sources, therefore, the accruals generated by these cash flows are less than perfectly correlated and tend to cancel out each other. Thomas (2002) argues that industrial diversification is not strictly associated with an increase in information asymmetry, which suggests that errors that outsiders make in forecasting segment cash flows are larger than the errors they make in predicting focused firm cash flows, and therefore the consolidated forecast may be more accurate than a forecast for a focused firm. This evidence is in favour of the information diversification hypothesis (Thomas, 2002) ${ }^{4}$, which predicts that "even if industrial diversification increases the complexity of firms, insiders' informational advantage over outsiders in assessing the value of their firms is partially or completely diversified away when their firms operate in multiple lines of business".

\footnotetext{
${ }^{4}$ In the context of agency cost and information asymmetry, Thomas (2002) distinguishes between the transparency hypothesis and information diversification hypothesis. The transparency hypothesis argues that industrially diversified firms have, compared with focused firms, larger forecast errors, more dispersion among analysts forecasts and larger revaluation around earnings announcements, and as a result, industrially diversified firms are less transparent than focused firms (Thomas, 2002). In contrast, the information diversification hypothesis claims that the aggregate nature of reported earnings for industrially diversified firms could imply that the errors the outsiders make in forecasting segment cash flows are imperfectly correlated across segments, then the consolidated forecast may be more accurate for industrially diversified than focused firms. As a result, industrial diversification has lower variability of earnings because earnings generated from different units are imperfectly correlated and tend to cancel each other (Jiraporn et al., 2008; El Mehdi and Seboui, 2011). This suggests that the resulting degree of information asymmetry and agency costs for industrially diversified firms depends on which effect dominates (Thomas, 2002).
} 
The information asymmetry between managers and outsiders creates an opportunity for industrially diversified firms to engage in earnings manipulation prior to a deal. Managers of industrially diversified firms have better opportunities to manipulate earnings across business units and there may be an intent to manipulate earnings. However, the accruals at the business segment level in industrially diversified firms would be less correlated than in focused firms, leading to a lower degree of observable discretionary accruals. To the extent that the accruals generated by different business units are imperfectly correlated and tend to offset each other at the firm's level, making it more difficult for managers to manipulate earnings via accruals, we expect a negative relationship between the degree of industrial diversification and earnings management by industrially diversified targets. Industrially diversified targets should have lower discretionary accruals than focused firms. Therefore, the first hypothesis is as follows:

H1: Discretionary accruals of industrially diversified targets in the years prior to M\&A transactions are lower than those of focused firms.

Most prior literature has looked at industrial diversification and geographic diversification together, but there is evidence that the two dimensions of diversification differ. Geographically diversified firms are larger and have more complex organisational structures than domestic firms (both industrially and non-industrially diversified firms) due to their operations in different countries (Bodnar et al., 1997). Also, geographically diversified firms are subject to different economic and political conditions, in terms of stability, competitive forces, growth opportunities and government regulations (Thomas, 2002). The additional information asymmetry between managers and investors in geographically diversified firms may contribute to an even more favourable environment for managers to engage in earnings manipulation prior to M\&As. Geographically diversified firms are probably less transparent than industrially diversified firms since foreign operations are even harder to monitor than domestic operations (Kim and Mathur, 2008). Consistent with this evidence, Chin et al. (2009) investigate the impact of geographic diversification on earnings management by Taiwanese firms and claim that earnings management increases with the degree of geographic diversification.

Foreign operations can also increase information asymmetry because local managers have more specific information about earnings and future cash flows generated by existing assets (Cahan et al., 2005). In addition to more serious information asymmetry problems 
between managers and shareholders, Duru and Reeb (2002) argue that less transparency in geographically diversified companies poses difficulties to financial analysts to analyse these companies' performance and assess their value. Similarly, Thomas (1999) claims that investors underestimate the persistence of foreign earnings due to a lack of understanding of geographically diversified firms' earnings. Consequently, an increased organisational complexity and less transparency in geographically dispersed firms may lead to an additional degree of information asymmetry compared to industrially diversified firms.

In contrast with this evidence, there is research that indicates that geographical diversification does not increase earnings manipulation. Cahan et al. (2005) argues that geographically diversified firms are more likely to disclose at a higher level and they claim that information asymmetry and agency costs arising from geographic diversification may be mitigated by managers disclosing voluntary information. Similarly, Jiraporn et al. (2008) argue that global diversification does not impact earnings management Overall, this evidence indicates that geographic diversification and industrial diversification are different, and therefore, we cannot assume that their impact on earnings management would be similar. As such, our second hypothesis is non-directional and investigates the consequences of geographical diversification on earnings management proxied by discretionary accruals.

H2: Discretionary accruals of geographically diversified targets in the years prior to M\&A transactions are different than those of focused targets.

\section{Research Methods}

\subsection{Abnormal Accruals Earnings Management Measures}

In line with recent studies on earnings management in M\&As (Louis, 2004; Ball and Shivakumar, 2008; Botsari and Meeks, 2008; Cohen and Zarowin, 2010), we adopt two cross-sectional variations of the Jones approach (1991); namely, the cross-sectional modified-Jones model (Dechow et al., 1995) and the performance-adjusted model (Kothari et al., 2005).

Our primary model is the cross-sectional modified-Jones model proposed by Dechow et al. (1995) with normal current accruals being estimated as follows:

$$
W C A_{i t} / A_{i t-1}=\beta_{0}+\beta_{1 j t}\left(1 / A_{i t-1}\right)+\beta_{2 j t}\left(\Delta R E V_{i t} / A_{i t-1}-\Delta R E C_{i t} / A_{i t-1}\right)+\varepsilon_{i t}
$$


Where:

$W C A_{i t}=$ current (working capital) accruals, respectively, for firm $i$ in event year $t$;

$\Delta R E V_{i t}=$ change in revenues for firm $i$ in event year $t$;

$\Delta R E C_{i t}=$ change in accounts receivables for firm $i$ in event year $t$;

$A_{i t-1}=$ beginning of period assets for firm $i$ in event year $t$

$\varepsilon_{i t}=$ error term for firm $i$ in event year $t$.

The dependent variable in the modified-Jones model is current accruals. We estimate this measure using the balance sheet approach and the cash flow approach. As balance sheet discretionary accruals estimates can be biased, we also use current accruals obtained from cash flow statements to mitigate the measurement error problem (Hribar and Collins, 2002; Ball and Shivakumar, 2008). We define current accruals following Botsari and Meeks (2008) and a detailed description of the calculation and definition of variables used are presented in Appendix A. The main motivation for using this proxy for accruals earnings management is that, unlike discretionary total accruals, ${ }^{5}$ the discretionary current accruals measure has a higher potential as an instrument of earnings manipulation (e.g., Botsari and Meeks, 2008) and most of the variation in total accruals is driven by current accruals (Sloan, 1996). In addition, Beneish (1998) claims that managing earnings through depreciation (as a component of non-current accruals) is potentially transparent.

Abnormal accruals are computed as the difference between the actual accruals and the normal component of accruals i.e. estimated non-discretionary accruals ${ }^{6}$. In order to reduce heteroscedasticity in the data, all variables in the accruals model are scaled by lagged assets. Abnormal accruals are estimated for event years $-2,-1$, and 0 , that is, the three years preceding a takeover, which are most likely to be affected by diversification ${ }^{7}$.

\footnotetext{
${ }^{5}$ Alternatively, the total discretionary accruals can be used as a proxy for earnings management. The estimation procedure for the total discretionary accruals is almost identical to that used within this paper. The only differences are that depreciation is not included in the definition of accruals, and property, plant and equipment are not included in the model as an explanatory variable.

${ }^{6}$ More specifically, following the literature we estimate the normal level of accruals for each two-digit SIC code industry grouping/year portfolio with at least 6 observations using a control sample (e.g., DeFond and Jiambalvo, 1994; Subramanyam, 1996; Botsari and Meeks, 2008). The control sample consists of all UK publicly listed firms that have the necessary data on Worldscope to estimate accruals, excluding the sample firms which had experienced a takeover event. The industry grouping/year portfolio parameter estimates from regression (1) are subsequently combined with firm-specific data to generate estimated prediction errors that represent the level of abnormal accruals for each firm. This approach controls for changes in economic conditions that affect current accruals across different industry groupings, but allows for coefficients to vary over time (DeFond and Jiambalvo, 1994; Cohen and Zarowin, 2010).

${ }^{7}$ All variables are trimmed at $1 \%$ and $99 \%$ to mitigate extreme observations.
} 
Our secondary accrual model is the performance-adjusted model proposed by Kothari et al. (2005). As suggested by Kothari et al. (2005), we include the lagged return on assets $\left(\mathrm{ROA}_{\mathrm{it}-1}\right)$ in the cross-sectional modified-Jones model in order to control for extreme performance as follows:

$$
\begin{aligned}
& W C A_{i t} / A_{i t-1}=\beta_{0}+\beta_{1 j t}\left(1 / A_{i t-1}\right)+\beta_{2 j t}\left(\Delta R E V_{i t} / A_{i t-1}-\Delta R E C_{i t} / A_{i t-1}\right)+ \\
& \beta_{3 j t}\left(R O A_{i t-1}\right)+\varepsilon_{i t}
\end{aligned}
$$

As our results are generally similar across the balance sheet approach and cash flow approach, we only report the results derived from both the cross-sectional modified-Jones model and the performance-adjusted model under the cash flow approach. The secondary model is used to estimate an additional measure of abnormal current accruals because Dechow et al. (1995) find that the modified-Jones model (Dechow et al., 1995) leads to misspecified tests when this model is applied to samples of firms experiencing extreme financial performance.

\subsection{Firm Industrial and Geographic Diversification Measures}

We follow the literature (e.g., Jiraporn et al., 2008; El Mehdi and Seboui, 2011) and distinguish between industrial or business diversification, where the target operates in many industrial segments, and geographical or global diversification, where the target operates in many countries. As industrial diversification and geographic diversification are expected to have a different effect on earnings management, we use different measures to examine the relationship between discretionary accruals and industrial diversification and geographic diversification. Totally there are six measures of industrial and geographic diversification used in the main empirical tests within this study.

For industrial diversification we use a dummy variable, MultiSegment, which equals 1 if the firm is industrially diversified and 0 otherwise. Industry groups (business segments) are defined by using two-digit SIC codes as reported by Worldscope database and SIC Industry classification. A firm is classified as industrially diversified if it reports data on sales for more than one industry group in Worldscope database. Geographic diversification is measured using Global, which equals 1 if the firm is globally diversified and 0 otherwise. The country/area groups were defined based on the geographic segment data reported by each company each year in Worldscope database. Specifically, a firm is considered as 
geographically diversified if it reports data on sales for other countries/geographic areas than UK in Worldscope database. ${ }^{8}$

Other four diversification measures are employed in this analysis: dummy variables associated with Single-segment Domestic firms $(S D)$, Multi-segment Domestic firms $(M D)$, Single-segment Global firms $(S G)$, and Multi-segment Global $(M G)$, as follows: (a) $S D$ equals 1 if the firm operates in only single industry segment and only one country(area), and 0 otherwise; (b) $M D$ equals 1 if the firm is only industrially diversified, and 0 otherwise; (c) $S G$ equals 1 if the firm is only globally diversified, and 0 otherwise, and (d) $M G$ equals 1 if the firm is both industrially and globally diversified, and 0 otherwise.

Additionally, as a robustness test, we repeat our analysis by using the Herfindahl index as a proxy for industrial diversification which is based on the distribution of the firm's sales across its various business segments. This measure of industrial diversification reflects the degree to which the revenue of a firm are concentrated within its industry segments (Thomas, 2002). Following prior research (Comment and Jarrell, 1995; Denis et al., 1997; Denis et al., 2002; Thomas, 2002; Jiraporn et al., 2008; Kim and Mathur, 2008; RodríguezPérez and Van Hemmen, 2010; El Mehdi and Seboui, 2011; Ataullah et al., 2014; Farooqi et al., 2014), we compute the Herfindahl index for firm $i$ year $t$ as:

$H_{E R F_{i, t}}=\sum\left(\frac{\text { SSale }}{\text { Sales }}\right)^{2}$

Where HERF i,t is the revenue-based Herfindahl index for firm $i$ in year $t$, and SSales is the industry segment sale of the firm and Sales is the firm's total sales for all reported industry segments (based on two-digit SIC codes reported by Datastream/Worldscope database) in that year, and the summation is over the industry segments in which the target operates. The Herfindahl index equals 1 for single-segment or focused firms, and it is less than 1 for multiple-segment or diversified firms. Therefore, the lower the index, the higher the degree of industrial diversification. It is noteworthy that all these diversification proxies are measured for each year of the event period, specifically the Year $0,-1$ and -2 , as the variation in targets' diversification over time will have a significant effect on the relationship between accruals earnings management and diversification.

\footnotetext{
${ }^{8}$ Worldscope database reports segmental data on many financial variables for both business segments (industries) and geographic areas (countries), such as Sales, Operating Income, Assets and Capital Expenditures. However, in the UK SSAP 25 requires disclosure of segmental data only on Sales, Operating Income and Assets, thus, we use data on Sales to classify industry groups and country/geographic area groups in this study.
} 


\subsection{Regression Analysis}

The objective of this study is to investigate whether earnings management is exacerbated or alleviated by targets' industrial and geographic diversification. To analyse the relationship between discretionary current accruals and targets' industrial and geographic diversification, we follow Lim et al. (2008) and run the following fixed-effects model $^{9}$ :

$$
\begin{aligned}
& \text { EM }_{i, t}=\beta_{0}+\beta_{1} \text { DIVERSIFICATION }_{i, t}+\beta_{2} \text { SIZE }_{i, t}+\beta_{3} \text { SGROW }_{i, t}+\beta_{4} L \text { VV }_{i, t}+ \\
& \beta_{5} \text { DECLINE }_{i, t}+\beta_{6} \text { LOSS }_{i, t}+\beta_{7} \text { TIME dummies }+\mu_{i}+\varepsilon_{i, t}
\end{aligned}
$$

Where:

$E M=$ Earning management measured by $a b \_w c a c c \_m j c f$ (abnormal working capital accruals estimated using the cross-sectional modified-Jones model under the cash-flow approach) or $a b \_w c a c c \_p m c f$ (abnormal working capital accruals estimated using the cross-sectional performance-adjusted model under the cash-flow approach).

DIVERSIFICATION= MultiSegment, Global, SD, MD, SG, MG and HERF;

MultiSegment=1 if the firm is industrially diversified, 0 otherwise;

Global $=1$ if the firm is globally diversified, 0 otherwise;

$S D=1$ if the firm operates in only single segment and only one country (it is neither industrially or globally diversified), 0 otherwise (Single-segment Domestic);

$M D=1$ if the firm is only industrially diversified, 0 otherwise (Multi-segment Domestic);

$S G=1$ if the firm is only globally diversified, 0 otherwise (Single-segment Global);

$M G=1$ if the firm is both industrially and globally diversified, 0 otherwise (Multi-segment Global);

$H E R F=1 /(1-$ revenue-based Herfindahl index $)$;

\footnotetext{
9 This model is not completely based on that of Lim et al. (2008). Their model includes two additional independent variables, specifically managerial ownership and institutional ownership. Datastream/Worldscope database does not provide data on these variables for all our sample targets, so if we kept only the targets for which Datastream/Worldscope provides this information, our target sample would have dropped significantly. However, to mitigate a potential omitted variable problem we use fixed-effects models which control for the impact of firm characteristics (such as managerial ownership and institutional ownership) not entered into the model. Other motivations for using fixed-effects models here are discussed later within this section.
} 


\section{Controls for firm characteristics:}

$S I Z E=$ the natural $\log$ of market capitalisation;

$S G R O W=$ sales growth;

$L E V=$ ratio of total debt to total equity;

$D E C L I N E=1$ if there is any decline in pre-managed earnings from those of the previous year, 0 otherwise;

$L O S S=1$ if pre-managed earnings are negative, 0 otherwise;

Time dummies = dummy variables for each year, which equals 1 for a certain fiscal year and 0 otherwise;

$\mu_{i}=$ individual specific effects;

$\varepsilon_{i, t}=$ random disturbance.

After all the diversification measures are determined for each event year, in particular the Year $0,-1$ and -2 (the first three years with an earnings release prior to a deal announcement), the model coefficients are estimated by using pooled data for the whole three-year period.

To date, most studies that examine the relationship between earnings management and diversification have employed OLS regression analysis. Following recent research (e.g., Rodríguez-Pérez and Van Hemmen, 2010; Roychowdhury et al., 2012), a panel data methodology is employed in this paper to examine the impact of industrial and geographic diversification on accruals earnings management. The main reason why the panel data methodology was used here is that it allows to control for unobservable heterogeneity (firmspecific effect) represented by parameters $\mu_{i}$, to obtain consistent estimates for regression parameters. ${ }^{10}$ Firms are heterogeneous, and as a result, there are always characteristics that are difficult to measure or data that is impossible to obtain, which leads to biased results. For example, attributes of managers, such as motivation and ability, or internal accounting policies vary across firms, but are assumed to be time-invariant for each firm. Therefore, a

\footnotetext{
${ }^{10}$ In this study, the panel dataset that has both cross-sectional and time variation is used (Cameron and Trivedi, 2010). As each time period of data is not independent of previous ones, model errors are very likely correlated (correlation over time or across individuals). Therefore, standard errors of panel-data estimators need to be adjusted (Cameron and Trivedi, 2010). Furthermore, in fixed-effects models, regressors may be correlated with the individual level effects (limited form of endogeneity), so that the consistent estimation of regression parameters requires controlling for fixed-effects.
} 
fixed-effects (FE) regression model is adopted to control for the impact of independent variables on the estimated coefficients, which is caused by variables not entered into the model, but which are acknowledged to be part of the firm heterogeneity. By including the individual effect into the regression (unobservable firm characteristics), fixed-effects models mitigate the omitted variable problem by capturing unobservable firm characteristics, such as managers' abilities or firm's accounting policies (Wooldridge, 2002). ${ }^{11}$

The main explanatory variables of interest are industrial and geographic diversification measures. We expect to find a negative relationship between the discretionary current accruals and industrial diversification measures. However, we do not make any directional prediction for the relationship between earnings management and geographic diversification.

We control for firm characteristics commonly associated with discretionary current accruals in the related literature, such as size, sales growth, leverage, decline and loss. Based on evidence provided by recent reviews of the earnings management literature (Doyle et al., 2007), we include the natural $\log$ of market capitalization $(S I Z E)$ to control for targets' size. Presumably, larger firms have stronger incentives and a higher ability to manipulate earnings through accruals than small firms, but higher costs associated with earnings management. The sales growth $(G R O W)$ is included to control for growth opportunities (McNichols, 2000). Highly leveraged firms are known to report greater income-increasing accruals, therefore we control for leverage by adding the ratio of total debt to total equity. Burgstahler and Dichev (1997) claim that firms' managers manipulate earnings upward to avoid earnings decreases and losses, therefore we first estimate pre-managed earnings for targets. We follow Lim et al. (2008) and calculate pre-managed earnings as net income before extraordinary items and preferred dividends divided by total assets net of discretionary accruals. Based on pre-managed earnings, then we create two dummy variables to capture managers' incentives to avoid earnings decreases and losses, DECLINE and LOSS, respectively. DECLINE equals 1 if there is any decline in pre-managed earnings from those of the previous year, and 0 otherwise. Finally, LOSS is 1 if pre-managed earnings are negative, and 0 otherwise ${ }^{12}$.

\footnotetext{
11 The Hausman specification test is conducted to choose between fixed-effects and random-effects as an alternative panel data approach.

${ }^{12}$ We employ dummy variables DECLINE and LOSS to avoid any econometric problems caused by the fact that discretionary current accruals are used as a dependent variable and indirectly as an explanatory variable in the regression model. The use of dummy variables alleviates this econometric concern (Lim et al., 2008).
} 
We also add time dummy variables to our model to control for changes to the economic, legal and institutional environment throughout our study period. Alternatively, we have also used a time dummy to control for the changes to the UK segmental reporting requirements: one change in 1990, with the adoption of GAAP SSAP 25, and then another change in 2006 when IAS 14R was implemented, as part of EU regulation requiring all listed European companies to report under IAS. This time dummy, which equals 1 if the fiscal year falls within the SSAP25 period (1990-2005) and 0 otherwise (if the fiscal year falls within the IAS 14R period 2006-2008), has been used in this study as we were concerned that the change in the segmental reporting requirements in the UK may distort the firm diversification measures used in our empirical analysis. ${ }^{13}$ However, the empirical results show that the coefficient of this time dummy is not statistically significant, so it was dropped from the empirical analysis and replaced with the time dummies for each year of the study period $(1990-2008)$.

\section{Sample and Data Description}

The sample of 229 UK targets used in this paper is a subset of the population of UK domestic M\&As announced between 1 January, 1990 and 31 December, 2008, inclusively. This period was selected as the necessary accounting data are available on the Datastream (DS)/Worldscope (WS) database starting in $1988 .^{14}$

The initial sample of 3173 UK M\&As was obtained using deal-specific information provided by the Thomson One Banker M\&A (TOB) database. This source was chosen as it provides the most comprehensive listing of UK deals, while offering the necessary dealspecific information, such as transaction date, deal value, premium, type of consideration and other details of transactions. The initial sample contains only UK targets in order to ensure

\footnotetext{
${ }^{13}$ The two generations of segment reporting - SSAP 25 and IAS 14R - differ significantly in terms of the principle of segment diversification, types of segments required for disclosure and the quantity of accounting data to be reported per segment (Aleksanyan and Danbolt, 2012). Prior literature on the effect of IFRS adoption on earnings quality shows that while the inherent flexibility in principles-based standards could generate greater opportunity for firms to manage earnings (Barth et al., 2008), tighter accounting standards (like IFRS) also reduce the variability of reported earnings and increase the value-relevance of earnings, which in turn will lower the level of accrual-based manipulation (Ewert and Wagenhofer, 2005). However, Armstrong et al. (2010) suggest that impact of IFRS adoption is conditional on pre-existing country-specific regulations and institutional frameworks, since these determine the level of accounting quality and reporting standards.

${ }^{14}$ Worldscope/Datastream data extend back to 1980, but its coverage is much more extensive from 1987 onwards (Alves et al., 2007). The study period ends in 2008, which was beginning of the global financial crisis, as this external shock had significant effect on both the M\&A activity, and firm value and financial and stock price performance. If the financial crisis period was included in the study period of this paper, the results of the earnings management analysis may have suffered from a serious measurement bias.
} 
data consistency, such as common disclosure requirements and accounting standards. No restriction was applied on the type of consideration in order to secure an as broad as possible sample of M\&As within the UK. ${ }^{15}$

More specifically, a transaction is included in the initial sample of 3173 if it satisfies the following three criteria:

(1) All the deals are M\&As. ${ }^{16}$

(2) The deal was announced between 1 January, 1990 and 31 December, 2008.

(3) The target company at the time of acquisition was an UK public company.

Following prior studies (e.g., Rossi and Volpin, 2004; Bertrand and Zitouna, 2008; Botsari and Meeks, 2008; Liu et al., 2009; Braga-Alves et al., 2010; Raman et al., 2013), a company is defined in the sample as a target if the percentage owned by the acquirer before the deal was less than 50\% and after the acquisition was higher than 50\%. Table 1 in Appendix B reconciles the initial sample of 3173 M\&As and the final sample of 229 targets and presents the sample selection process in detail. Outliers in raw data on all variables used to calculate accruals were eliminated by trimming the sample at $1 \%$ and $99 \%$. Segmental data for each target in the sample were obtained from the Worldscope database over the period 1990-2008. Missing data on industry segments and data on geographic segments were collected manually using their annual reports from the Nexis/Lexis database.

In summary of the sample selection process, a transaction is included in the sample of 229 M\&As if it meets the following criteria:

1) All the deals are mergers and acquisitions.

2) The deal was announced between 1 January, 1990 and 31 December, 2008.

3) The target at the time of the acquisition was a UK public company.

4) The deal was completed and the percentage of the target's shares owned by the acquirer before the deal was less than $50 \%$ and after the acquisition was higher than $50 \%$.

5) The deal was not a special type of M\&As, such as financial acquirer, acquirer is a white knight, liquidation deals and bankruptcy acquisition.

6) The deal was classified as a Tender Offer/Tender Merger transaction by the TOB M\&A database.

7) The target is a non-financial company.

8) The target is (was at the time of the acquisition) not a cross-listing and non-LSE company.

${ }^{15}$ It is reasonable to assume that the motive for earnings management should exist in all mergers and acquisitions regardless of the consideration received by targets' shareholders, therefore cash, stock-for-stock and mixed transactions were included within the sample.

${ }^{16}$ All the transactions classified as mergers and acquisitions according to the TOB M\&A database. 
9) The target company has identifiable Datastream/Worldscope codes.

10) The target has the necessary Datastream/Worldscope data to estimate discretionary accruals (annual reports in GBP), has no missing financial data and has financial statement data available for at least four consecutive years prior to the deal as well.

11) The target does not have zero cash and/or sales.

12) There are no outliers among the sample companies (undertaken trimming at $1 \%$ and $99 \%$ ).

13) The target is an UK publicly listed company, whose shares had been traded on LSE Main market.

14) The target has Worldscope segmental data available for four consecutive years prior to the deal, and HERF value is equal or lower than 1.

The final sample of 687 observations used for descriptive statistics purposes within this study results from the pooled dataset for 229 targets and three-year event period, in particular the Year 0, -1 and -2. However, the sample size varies within the empirical analysis from 687 to 662 observations due to missing data on various diversification and control variables.

\section{Empirical Results}

\subsection{Descriptive statistics}

Panel A of Table 2 presents the distribution of the targets per industry. Following Cohen and Zarowin (2010), we formed 17 industry groupings based on 2-digit SIC codes to estimate cross-sectional discretionary accruals. The results reported in Panel A of Table 2 indicate that the deals in our sample are spread across a variety of industries, with the greatest concentration of firms in Computer Equipment and Services (41 firms or 17.90\%) and All Others (44 firms or 19.21\%), respectively. Panel B of Table 2, which presents the distribution of deals per year, shows that a larger number of deals occurred over the period 1995-2000, which is consistent with prior studies in the UK (e.g., Botsari and Meeks, 2008). 
Table 2

Panel A: Distribution by Target Industry (Two-digit SIC Codes)

\begin{tabular}{|c|c|c|c|}
\hline Group Name & Two-digit SIC Code & Freq. & $\%$ \\
\hline Oil and gas & 13,29 & 4 & 1.75 \\
\hline Food products & 20 & 9 & 3.93 \\
\hline Paper and paper products & $24,25,26,27$ & 16 & 6.99 \\
\hline Chemical products & 28 & 10 & 4.37 \\
\hline Manufacturing & $30-34$ & 24 & 10.48 \\
\hline Computer equipment and services & 35,73 & 41 & 17.90 \\
\hline Electronic equipment & 36 & 12 & 5.24 \\
\hline Transportation & $37,39,40-42,44,45$ & 13 & 5.68 \\
\hline Scientific instruments & 38 & 7 & 3.06 \\
\hline Communications & 48 & 6 & 2.62 \\
\hline Electric, gas and sanitary services & 49 & 10 & 4.37 \\
\hline Durable goods & 50 & 11 & 4.80 \\
\hline Retail & $53,54,56,57,59$ & 10 & 4.37 \\
\hline Eating and drinking establishments & 58 & 3 & 1.31 \\
\hline Entertainment services & $70,78,79$ & 8 & 3.49 \\
\hline \multirow[t]{4}{*}{ Health } & 80 & 1 & 0.44 \\
\hline & $10,12,14,15,16,17$ & & \\
\hline & $21,22,23,47$ & & \\
\hline & $51,52,55,72,75,76$ & & \\
\hline All others & $82,83,84,87,89,92,95$ & 44 & 19.21 \\
\hline Total & & 229 & 100.00 \\
\hline
\end{tabular}

Table 3 presents the distribution of the targets by firm-type and year. In Panel A we present the time-series of deals and firm type (diversified vs. focused firms). Out of 229 targets, the sample consists of 143 (62.45\%) diversified firms and 86 (37.55\%) focused firms. Following prior research (e.g., Denis et al., 2002), a firm is classified as industrially diversified if it reports data on sales for more than one industry group in Worldscope database; a firm is considered as geographically diversified if it reports data on sales for other countries/geographic areas than UK Worldscope database. However, SSAP 25 is not strict regarding the identification of industry segments (or classes of business) in which the firm operates, which allows discretion to managers in the UK to determine the industry segments, so that the reported segmental data helps investors to assess the risk and performance of their company. 
Table 2 (Continued)

\section{Panel B: Distribution by Year}

\begin{tabular}{|c|c|c|}
\hline Year & $\begin{array}{r}\text { No. of } \\
\text { deals }\end{array}$ & $\begin{array}{r}\text { Value of deals } \\
(£ \mathrm{~m})\end{array}$ \\
\hline 1992 & 2 & 28.80 \\
\hline 1993 & 2 & 79.89 \\
\hline 1994 & 14 & $1,896.64$ \\
\hline 1995 & 13 & $14,222.08$ \\
\hline 1996 & 14 & $10,703.55$ \\
\hline 1997 & 26 & $6,610.75$ \\
\hline 1998 & 29 & $6,484.20$ \\
\hline 1999 & 35 & $14,772.75$ \\
\hline 2000 & 34 & $17,256.55$ \\
\hline 2001 & 10 & $1,993.34$ \\
\hline 2002 & 5 & 336.45 \\
\hline 2003 & 8 & $1,996.87$ \\
\hline 2004 & 4 & 313.77 \\
\hline 2005 & 12 & $7,520.52$ \\
\hline 2006 & 10 & $6,955.93$ \\
\hline 2007 & 6 & $1,316.81$ \\
\hline 2008 & 5 & $1,971.90$ \\
\hline Total & 229 & $94,460.80$ \\
\hline
\end{tabular}

As a result, this measurement of corporate industrial diversification based on reported segmental data may not accurately capture the extent of real corporate diversification (Ataullah et al., 2014). Worldscope database reports segmental data for up to ten industry segments. Geographic segment data provided by Worldscope is less detailed than industry segment data because there is no strict definition of geographic segments required by SSAP $25^{17}$. Thus, an individual geographic segment reported on Worldscope database represents a single country or might be a broad geographic region. Wordscope database also limits the number of geographic segments to ten. In Panel B of Table 3 we report the distribution of the targets by firm type (focused firms, domestic and multinational, and diversified firms, domestic and multinational).

\footnotetext{
${ }^{17}$ SSAP 25 defines a geographic segment as "a geographic area comprising an individual country or a group of countries in which an entity operates, or to which it supplies products of services". There is no requirement prescribed by SSAP 25 regarding grouping for geographic areas, determination of reportable geographic segments in the UK must depend on the judgement of the directors. The method of grouping selected by directors should reflect the purpose of presenting segmental information and all differences among international business environments. Consequently, there might be differences in the way two companies operating in the same countries report their foreign operations.
} 
Table 3

Panel A: Distribution by Firm-Type and Year

\begin{tabular}{lccc}
\hline Deal Year & Focused Firms & Diversified Firms & Total Firms \\
\hline 1992 & 1 & 1 & 2 \\
1993 & 0 & 2 & 2 \\
1994 & 10 & 4 & 14 \\
1995 & 4 & 9 & 13 \\
1996 & 3 & 11 & 14 \\
1997 & 9 & 17 & 26 \\
1998 & 13 & 16 & 29 \\
1999 & 11 & 24 & 35 \\
2000 & 12 & 22 & 34 \\
2001 & 2 & 8 & 10 \\
2002 & 4 & 1 & 5 \\
2003 & 6 & 2 & 8 \\
2004 & 1 & 3 & 4 \\
2005 & 2 & 10 & 12 \\
2006 & 5 & 5 & 10 \\
2007 & 2 & 4 & 6 \\
2008 & 1 & $\mathbf{1 4 3}$ & $\mathbf{2 2 9}$ \\
\hline Total & $\mathbf{8 6}$ & Focused firms are firms operating in only single industrial segment \\
\hline Notes: & & & \\
whereas, diversified firms are firms operating in more than one industrial \\
segment.
\end{tabular}

Table 3 (Continued)

Panel B: Matrix of Ranking Focused and Diversified Firms into Domestic and Multinational firms

\begin{tabular}{|c|c|c|c|c|}
\hline & \multicolumn{2}{|c|}{ Focused Firms (86) } & \multicolumn{2}{|c|}{ Diversified Firms (143) } \\
\hline & Domestic & Multinational & Domestic & Multinational \\
\hline Number of firms & 40 & 46 & 48 & 95 \\
\hline \multicolumn{5}{|c|}{$\begin{array}{l}\text { Notes: Focused firms are firms operating in only single industrial segment whereas, diversifiec } \\
\text { firms are firms operating in more than one industrial segment; focused and diversified firms are } \\
\text { classified into domestic and multinational firms. Domestic firms are firms operating in only single } \\
\text { country whereas, multinational firms are firms operating in more than one country. We use a } \\
\text { combination of industrial segment and geographic segment data to get four groups of firms. }\end{array}$} \\
\hline
\end{tabular}

We use a combination of industry segments and geographic region data to obtain four groups of firms. It is worth noting that multinational diversified firms have the largest number of firms (95), representing more than $41.48 \%$ of the total targets. 
Table 4 presents descriptive statistics for firm characteristics by firm-type. In terms of size, diversified firms are significantly higher than focused firms. For example, the mean of sales for the diversified firms is $£ 475.81$ mil., while the mean for focused firms is $£ 224.12$ mil. They also have much higher total assets and market capitalization. The differences in means for these firm characteristics (sales, total assets and market capitalization) are statistically significant. Diversified firms carry more debt than focused firms, the mean debt to equity ratio for diversified firms is $66.79 \%$ while the mean for focused firms is only $30.23 \%$. The difference is also statistically significant. They also have fewer growth opportunities, and apparently are more profitable. The difference in means for return on assets, however, is not statistically significant. These characteristics are generally consistent with those reported in prior studies (e.g., Jiraporn et al., 2008).

The correlations between target's Size, Sales Growth Ratio, Leverage (Debt to Equity Ratio), Decline and Loss dummy variables were checked and the untabulated results show that most of the pair-wise correlations among these variables are relatively low around $1+0.20$, which suggests that there is no multicolliniarity problem in this study. ${ }^{18}$ The analysis of partial correlations is also repeated for alternative measures of diversifications and Decline and Loss dummy variables and the results are qualitatively the same.

Table 4

Summary Statistics for Firm Characteristics by Firm-Type

\begin{tabular}{|c|c|c|c|c|c|c|}
\hline & \multicolumn{2}{|c|}{ Focused Firms } & \multicolumn{2}{|c|}{ Diversified Firms } & \multicolumn{2}{|c|}{ Means differences } \\
\hline & Mean & SD & Mean & SD & t-statistics & $\mathrm{P}$-value \\
\hline Sales (£m) & 224.1238 & 442.2005 & 475.8087 & 785.3006 & -6.0540 & 0.0000 \\
\hline $\begin{array}{l}\text { Total Assets (£m) } \\
\text { Market }\end{array}$ & 149.0268 & 244.7106 & 455.2337 & 795.8726 & -6.2630 & 0.0000 \\
\hline Capitalization (£m) & 155.6689 & 227.2510 & 380.1926 & 756.2101 & -4.5320 & 0.0000 \\
\hline Net Income (£m) & 2.4317 & 30.0965 & 19.7564 & 68.7740 & -4.5080 & 0.0000 \\
\hline Return on Assets (\%) & 0.0405 & 0.1323 & 0.0513 & 0.1010 & 0.2860 & 0.7748 \\
\hline Sales Growth Ratio (\%) & 0.1149 & 0.3051 & 0.0621 & 0.2091 & 2.0360 & 0.0417 \\
\hline Debt to Equity Ratio & 0.3023 & 4.1030 & 0.6679 & 1.9309 & -2.7920 & 0.0052 \\
\hline
\end{tabular}

Notes: Sales, total assets and market capitalization and net income are the target's Net Sales, Total Assets, Market Capitalization and Net Income before Extraordinary Items and Preferred Dividends across the event period, specifically the Year 0, -1 and -2. The corresponding Worldscope items are WC01001, WC02999, WC08001, and WC01551 respectively. Return on Assets is computed as Net Income before Extraordinary Items and Preferred Dividends (WC01551) over the lagged Total Assets (WC02999). Sales Growth Ratio is computed as percentage change in sales. Debt to Equity Ratio is computed as Total Debt (WC03255) over Common Equity (WC03501).

\footnotetext{
${ }^{18}$ To double-check the results of the pair-wise correlations among explanatory variables, the VIF (varianceinflation-factor) test and CI (condition index) test are employed and the results of the previous analysis are supported by these additional tests which provide further evidence that none of the explanatory variables are highly correlated with other variables.
} 


\subsection{Results of Accruals Tests}

The descriptive statistics for the discretionary current accruals derived from the crosssectional modified-Jones model under the cash-flow approach are presented in Table 5. The reported residuals measure the level of discretionary current accruals as a percentage of lagged total assets. Firstly, we compare the abnormal accruals of single-segment firms to those of multi-segment firms, regardless of whether they operate only domestically or geographically. The average discretionary accruals for the single-segment domestic firms and single-segment global firms are 0.0052 (median -0.0014) and 0.0070 (median 0.0122) respectively, while the average discretionary accruals for the multi-segment domestic firms and multi-segment global firms are -0.0084 (median -0.0110) and 0.0023 (median 0.0085), respectively. Thus, there is some evidence that multi-segment firms have a lower degree of earnings management than single-segment firms.

The second comparison is between domestic firms and global firms, regardless of whether they operate in one or many industries. The average discretionary current accruals for domestic single-segment firms and domestic multi-segment firms are 0.0052 (median 0.0014 ) and -0.0084 (median 0.0110) respectively, while the average for the global singlesegment firms and global multi-segment firms are 0.0070 (median 0.0122) and 0.0023 (median 0.0085). Therefore, overall this evidence reveals that geographic diversification is associated with a higher degree of earnings management compared with domestic firms. Finally, the discretionary accruals for firms that are both industrially and geographically diversified (Multi-segment global) are 0.0023 (median 0.0085). This value is, on average, higher than that for only industrially diversified firm, and also lower than that for firms that are only industrially diversified (single-segment global). Thus, it seems that industrial diversification helps mitigate earnings management, but geographic diversification does not do so. 


\section{Table 5 Descriptive Statistics for Discretionary Current Accruals Estimated using the Cross-Sectional Modified Jones Model (ab_wcacc_mjcf)}

\begin{tabular}{lrr}
\hline Domestic & $\begin{array}{c}\text { Single-segment } \\
\text { Mean (Median) }\end{array}$ & $\begin{array}{r}\text { Multi-segment } \\
\text { Mean (Median) }\end{array}$ \\
\hline Global & -0.0052 & -0.0084 \\
& 0.0014 & 0.0110 \\
& 0.0122 & 0.0023 \\
Notes: The results for the cross-sectional modified Jones Model under the cash \\
flow approach are based on the estimated discretionary accruals for 229 UK \\
targets during the period 1990-2008. Focused firms are firms operating in only \\
single industrial segment whereas, diversified firms are firms operating in more \\
than one industrial segment; focused and diversified firms are classified into \\
domestic and multinational firms. Domestic firms are firms operating in only \\
single country, whereas, multinational firms are firms operating in more than \\
one country. We use a combination of industrial segment and geographic \\
segment data to get four groups of firms. The corresponding number of \\
observations for each group is given next in brackets.
\end{tabular}

\subsection{Relationship between Accruals Earnings Management and Targets' Industrial and}

\section{Geographic Diversification}

Panel A of Table 6 reports the results of the fixed-effects (FE) panel data regression analysis where the dependent variable is the discretionary current accruals estimated using the cross-sectional modified-Jones model $\left(a b_{-} w c a c c_{-} m j c f\right) .{ }^{19}$ As previously mentioned, abnormal accruals are estimated for event years $-2,-1$, and 0 , that is, the three years preceding a takeover, which are most likely to be affected by industrial and geographical diversification. ${ }^{20}$

To test the relationship between earnings management and industrial diversification, we use Model 1 which includes a dichotomous variable MultiSegment, that is equal to 1 if the firm is industrially diversified and 0 otherwise. Control variables are also included in Model 1. The coefficient for the multi-segment dummy variable is negative and statistically significant at the 5\% level, suggesting that industrial diversification mitigates earnings management which is consistent with H1. The coefficient for this variable of -0.0607 implies

\footnotetext{
${ }^{19}$ The choice of this panel data approach was made as the Hausman test statistic is statistically significant, therefore the fixed-effects model is appropriate.

${ }^{20}$ For example if a takeover was conducted in 2000 , we calculate abnormal accruals for event years $-2,-1$, and 0 (the three years preceding a takeover), specifically 1997, 1998, and 1999 respectively.
} 
that earnings management is reduced by $6.07 \%$ on average when the target is industrially diversified.

The results for geographic diversification are presented in Panel B of Table 6. Model 2 tests the relationship between discretionary current accruals and geographic diversification, which is measured by a dummy variable Global that it is equal to 1 if the firm is globally diversified and 0 otherwise. The coefficient for this variable is positive, but not statistically significant which suggests that global diversification increases earnings management, this evidence is in line with $\mathrm{H} 2$ that the degree of earnings management of geographically diversified targets is different than those of focused targets. A possible explanation for these different results for geographic diversification is that geographically diversified companies are larger and have more complex organisational structures than domestic firms due to their operations in different countries (Bodnar et al., 1997) which may offer more opportunities for managers in geographically diversified firms to manipulate reported earnings. This complexity can lead higher costs of monitoring managerial decision making in geographically diversified firms (Bodnar et al., 1997) and also poses difficulties to financial analysts to analyse these companies' performance and assess their value (Duru and Reeb, 2002).

Finally, in Model 3 in Panel $\mathrm{C}$ of Table 6, three dummy variables ( $M D, S G$, and $M G)$ are included to distinguish among multi-segment domestic firms, single-segment global firms, and multi-segment global firms. The coefficient for the multi-segment domestic firms is negative and statistically significant at the $10 \%$ level. This result suggests that a combination of industrial and geographic diversification mitigates earnings management by $6.42 \%$ on average which is also consistent with H1. Our results are in line with Jiraporn et al. (2008) who provide evidence of a negative relation between earnings management and industrial diversification and show that a combination of industrial and global diversification helps alleviate earnings. El Mehdi and Seboui (2011) also find that industrial diversification decreases earnings management by US firms. Among the control variables, the size coefficient appears to be positive and significant in almost six models. In line with other studies, larger firms tend to manipulate earnings more than smaller ones supporting the argument that larger firms take advantage of their more severe information asymmetry (Rodríguez-Pérez and Van Hemmen, 2010). 
Table 6 Regressions of Discretionary Current Accruals Estimated Using the Cross-Sectional Modified-Jones Model on Industrial and Geographic Diversification Dummies and Controls

Panel A: Earnings management and Industrial Diversification

\begin{tabular}{llllllllll}
\hline & MultiSegment & SIZE & SGROW & LEV & DECLINE_1 & LOSS_1 & Observations & R-squared & F \\
\hline \multirow{2}{*}{ Model 1} & $\mathbf{- 0 . 0 6 0 7 * *}$ & $\begin{array}{llllll}0.0297 * * \\
(0.0134)\end{array}$ & $\begin{array}{l}-0.00755 \\
(0.0227)\end{array}$ & $\begin{array}{l}-0.00199 \\
(0.0021)\end{array}$ & $\begin{array}{l}0.0449 * * * \\
(0.0059)\end{array}$ & $\begin{array}{l}0.0589^{* * *} \\
(0.0113)\end{array}$ & 662 & 0.049 & 7.20 \\
\hline
\end{tabular}

Panel B: Earnings management and Geographic Diversification

\begin{tabular}{|c|c|c|c|c|c|c|c|c|c|}
\hline & Global & SIZE & SGROW & $L E V$ & DECLINE_l & LOSS_l & Observations & R-squared & $\mathrm{F}$ \\
\hline Model 2 & $\begin{array}{l}\mathbf{0 . 0 0 5 8} \\
(\mathbf{0 . 0 3 3 5})\end{array}$ & $\begin{array}{l}0.0240^{*} \\
(0.0140)\end{array}$ & $\begin{array}{l}-0.00884 \\
(0.0226)\end{array}$ & $\begin{array}{l}-0.0027 \\
(0.0018)\end{array}$ & $\begin{array}{l}0.0451 * * * \\
(0.0058)\end{array}$ & $\begin{array}{l}0.0577 * * * \\
(0.0113)\end{array}$ & 662 & 0.066 & 7.20 \\
\hline
\end{tabular}

Panel C: Earnings management and Industrial and Geographic Diversification

\begin{tabular}{|c|c|c|c|c|c|c|c|c|c|c|c|}
\hline & $M D$ & $S G$ & $M G$ & SIZE & SGROW & $L E V$ & DECLINE_l & $L O S S_{-} 1$ & Observations & R-squared & $\mathrm{F}$ \\
\hline Model 3 & $\begin{array}{l}-0.0642 * \\
(0.0328)\end{array}$ & $\begin{array}{l}\text { 0.0251 } \\
(\mathbf{0 . 0 5 1 3})\end{array}$ & $\begin{array}{l}-\mathbf{- 0 . 0 3 9 9} \\
(0.0385)\end{array}$ & $\begin{array}{l}0.0307 * * \\
(0.0134)\end{array}$ & $\begin{array}{l}-0.00746 \\
(0.0225)\end{array}$ & $\begin{array}{l}-0.0019 \\
(0.0021)\end{array}$ & $\begin{array}{l}0.0449 * * * \\
(0.0058)\end{array}$ & $\begin{array}{l}0.0586 * * * \\
(0.0113)\end{array}$ & 662 & 0.0464 & 6.70 \\
\hline
\end{tabular}

Notes: This table presents FE regression estimates for the pooled dataset for 229 targets and three-year event period, in particular the Year 0 , -1 and -2 (the three years preceding the takeover). The dependent variable is discretionary current accruals estimated using using cross-sectional modified Jones model (ab_wcacc_mjcf) in all these models. $S D$ is a dummy variable that equals 1 if the firm operates in only single industry segment and only one country, and 0 otherwise. $M D$ equals 1 if the firm is only industrially diversified, and 0 otherwise. $S G$ equals 1 if the firm is only globally diversified, and 0 otherwise. $M G$ equals 1 if the firm is both industrially and globally diversified, and 0 otherwise. MultiSegment equals 1 if the firm is industrially diversified, 0 otherwise. Global equals 1 if the firm is globally diversified, 0 otherwise. Industry groups are defined by using two-digit SIC codes as reported by Worldscope database and SIC Industry classification. A firm is classified as industrially diversified if it reports more than one industry group in Worldscope database. The country/area groups are defined based on the geographic segment data reported by a company each year in Worldscope database. Specifically, a firm is considered as geographically diversified if it reports sales for other countries than UK in Worldscope database. SIZE represents the natural log of market capitalisation. SGROW is sales growth ratio. The $L E V$ ratio is total debt to total equity. DECLINE_l is a dummy variable which equals 1 if there is any decline in pre-managed earnings (computed on the basis of discretionary current accruals estimated using the cross-sectional Modified-Jones Model) from those of the previous year, and 0 otherwise. LOSS_l is a dummy variable which equals 1 if pre-managed earnings (computed on the basis of discretionary current accruals estimated using the cross-sectional Modified-Jones Model) are negative, and 0 otherwise. All the models include an intercept and firm-fixed effects. Time dummies are also included within these three regression models to control for differences in economic, legal and institutional conditions throughout our study period (1990-2008). The value of cluster-robust standard errors is in brackets. $* * *, * * *$ indicate that the parameter estimate is significantly different from zero at the $1 \%$, $5 \%$ or $10 \%$ level respectively. 


\subsection{Robustness Check: Alternative Measures of Earnings Management and Industrial and} Geographic Diversification

So far, we have used the discretionary current accruals estimated from the modifiedJones model ( $a b_{-}$wcacc_mjcf $)$to examine the relation between earnings management and targets' industrial and geographic diversification. To test the robustness of our results, we use discretionary current accruals from the performance-adjusted model (ab_wcacc_pmcf) as an alternative proxy for earnings management. ${ }^{21}$ The results of these robustness tests are presented in Table 7. This table shows the results of the FE regression models where the dependent variable is the discretionary current accruals estimated from the performanceadjusted model (ab_wcacc_pmcf). In Model 1 in Panel A of Table 7, the multi-segment dummy variable is negative and statistically significant at the $5 \%$ level, which is consistent with $\mathrm{H} 1$ that industrial diversification is associated with less earnings management by targets. The results presented by Panel B of Table 7 show that the global dummy variable, Global, is positive and not statistically significant in Model 2, which is in line with $\mathrm{H} 2$. These findings are similar to previous results obtained by using the discretionary current accruals estimated from the modified-Jones model. Finally, in Model 3 in Panel C of Table 6, the multi-segment domestic dummy variable is negative, but is not statistically significant.

To further check the robustness of our results, we use an alternative measure of industrial diversification. Following prior studies on diversification (e.g., Berger and Ofek, 1995; Comment and Jarrell, 1995; Jiraporn et al., 2008; Lim et al., 2008), we employ the Herfindahl index as a proxy for industrial diversification, the lower the index, the higher the degree of industrial diversification. For ease of interpretation, we use the reciprocal of the Herfindahl index in the regression analysis. Table 8 presents the FE regression results using this alternative measure of diversification. Model 1 includes the discretionary current accruals estimated from the modified-Jones model (ab_wcacc_mjcf) and Model 2 includes the discretionary current accruals estimated from the performance-adjusted model $\left(a b \_w c a c c \_p m c f\right)$. In both models, Model 1 and Model 2, the coefficient for the reciprocal of the Herfindahl index is negative and statistically significant at $1 \%$ and $5 \%$, respectively. The evidence confirms the previous results obtained by using the multi-segment dummy

\footnotetext{
21 The results also hold when abnormal current accruals measures are estimated using median regression (instead of OLS), suggesting that it is unlikely that the results are driven by outliers.
} 
variable. In conclusion, when we use alternative measures of earnings management and industrial diversification, we obtain qualitatively similar results. ${ }^{22}$

As an alternative measure of geographic diversification, we follow Farooqi et al. (2014) and employ a geographic Herfindahl index $(G H E R F)$ in this study. Similar to industrial Herfindahl index, this variable is based on the distribution of the firm's sales across its various geographic segments and reflects the degree to which the revenue of a firm are concentrated within its geographic segments. Unreported results show that the coefficient for GHERF is negative and statistically insignificant. This evidence is, generally speaking, in line with $\mathrm{H} 2$, however, also suggests that the relationship between discretionary accruals for targets and geographic diversification prior to M\&As is not very consistent.

\footnotetext{
${ }^{22}$ As additional robustness tests, we have also followed prior literature and used two continuous variables as alternative measures of industrial and geographic diversification, in particular the number of business segments (TNBS) and the number of geographic segments (TNGS) (Berger and Ofek, 1995; Denis et al., 1997; Denis et al., 2002; Thomas, 2002; Kim and Mathur, 2008; Gande et al., 2009). The results of the empirical analysis show that the coefficient for TNBS is negative and statistically significant, which is consistent with $\mathrm{H} 1$ and similar to the results for our main empirical tests by using MultiSegment variable for industrial diversification. However, when $T N G S$ variable is used for geographic diversification instead of Global, the coefficient becomes negative, but it is still statistically insignificant.
} 
Table 7 Regressions of Discretionary Current Accruals Estimated Using the Cross-Sectional Performance-adjusted Model on Industrial and Geographic Diversification Dummies and Controls

Panel A: Earnings management and Industrial Diversification

\begin{tabular}{|c|c|c|c|c|c|c|c|c|c|}
\hline & MultiSegment & SIZE & SGROW & $L E V$ & DECLINE_2 & LOSS_2 & Observations & R-squared & $\mathrm{F}$ \\
\hline Model 1 & $\begin{array}{l}-0.0482 * * \\
(0.0240)\end{array}$ & $\begin{array}{l}0.0250 * \\
(0.0133)\end{array}$ & $\begin{array}{l}0.0113 \\
(0.0258)\end{array}$ & $\begin{array}{l}-0.001 \\
(0.00226)\end{array}$ & $\begin{array}{l}0.0482 * * * \\
(0.00610)\end{array}$ & $\begin{array}{l}0.0758 * * * \\
(0.0143)\end{array}$ & 662 & 0.0685 & 8.00 \\
\hline
\end{tabular}

Panel B: Earnings management and Geographic Diversification

\begin{tabular}{|c|c|c|c|c|c|c|c|c|c|}
\hline & Global & SIZE & SGROW & $L E V$ & DECLINE_2 & LOSS_2 & Observations & R-squared & $\mathrm{F}$ \\
\hline Model 2 & $\begin{array}{l}0.00419 \\
(0.0354)\end{array}$ & $\begin{array}{l}0.0203 \\
(0.0138)\end{array}$ & $\begin{array}{l}0.0105 \\
(0.0257)\end{array}$ & $\begin{array}{l}-0.00161 \\
(0.00197)\end{array}$ & $\begin{array}{l}0.0489 * * * \\
(0.00608)\end{array}$ & $\begin{array}{l}0.0748 * * * \\
(0.0141)\end{array}$ & 662 & 0.0879 & 7.70 \\
\hline
\end{tabular}

Panel C: Earnings management and Industrial and Geographic Diversification

\begin{tabular}{|c|c|c|c|c|c|c|c|c|c|c|c|}
\hline & $M D$ & $S G$ & $M G$ & SIZE & SGROW & $L E V$ & DECLINE_2 & $L O S S \_2$ & Observations & R-squared & $\mathrm{F}$ \\
\hline Model 3 & $\begin{array}{l}-0.0475 \\
(0.0325)\end{array}$ & $\begin{array}{l}\mathbf{0 . 0 2 4} \\
(0.0512)\end{array}$ & $\begin{array}{l}-\mathbf{- 0 . 0 3 0 6} \\
(0.0400)\end{array}$ & $\begin{array}{l}0.0256^{*} \\
(0.0133)\end{array}$ & $\begin{array}{l}0.0115 \\
(0.0257)\end{array}$ & $\begin{array}{l}-0.00096 \\
(0.00226)\end{array}$ & $\begin{array}{l}0.0484 * * * \\
(0.00611)\end{array}$ & $\begin{array}{l}0.0752 * * * \\
(0.0141)\end{array}$ & 662 & 0.0627 & 7.37 \\
\hline
\end{tabular}

Notes: This table presents FE regression estimates for for the pooled dataset for 229 targets and three-year event period, in particular the Year $0,-1$ and -2 (the three years preceding the takeover). The dependent variable is discretionary current accruals estimated using the cross-sectional performance-adjusted Model (ab_wcacc_pmcf) in all these models. $S D$ is a dummy variable that equals 1 if the firm operates in only single industry segment and only one country, and 0 otherwise. $M D$ equals 1 if the firm is only industrially diversified, and 0 otherwise. $S G$ equals 1 if the firm is only globally diversified, and 0 otherwise. $M G$ equals 1 if the firm is both industrially and globally diversified, and 0 otherwise. MultiSegment equals 1 if the firm is industrially diversified, 0 otherwise. Global equals 1 if the firm is globally diversified, 0 otherwise. Industry groups are defined by using two-digit SIC codes as reported by Worldscope database and SIC Industry classification. A firm is classified as industrially diversified if it reports more than one industry group in Worldscope database. The country/area groups are defined based on the geographic segment data reported by a company each year in Worldscope database. Specifically, a firm is considered as geographically diversified if it reports sales for other countries than UK in Worldscope database. SIZE represents the natural $\log$ of market capitalisation. SGROW is sales growth ratio. The $L E V$ ratio is total debt to total equity. DECLINE_2 is a dummy variable which equals 1 if there is any decline in pre-managed earnings (computed on the basis of discretionary current accruals estimated using the cross-sectional performance-adjusted Kothari Model) from those of the previous year, and 0 otherwise. LOSS_2 is a dummy variable which equals 1 if pre-managed earnings (computed on the basis of discretionary current accruals estimated using the cross-sectional performance-adjusted Model) are negative, and 0 otherwise. All the models include an intercept and firm-fixed effects. Time dummies are also included within these three regression models to control for differences in economic, legal and institutional conditions throughout our study period (1990-2008). The value of cluster-robust standard errors is in brackets. ***,**, indicate that the parameter estimate is significantly different from zero at the $1 \%, 5 \%$ or $10 \%$ level, respectively. 
Table 8

Regressions of Discretionary Current Accruals Proxies, the Herfindahl Index and Controls

\begin{tabular}{lcc}
\hline VARIABLES & $(1)$ & $(2)$ \\
1/HERF & $a b \_w c a c c \_m j c f$ & $a b \_w c a c c \_p m c f$ \\
\hline SIZE & $\mathbf{- 0 . 0 2 1 5 * * *}$ & $\mathbf{0 . 0 1 9 0 * *}$ \\
& $\mathbf{( 0 . 0 0 7 9 3 )}$ & $\mathbf{( 0 . 0 0 8 6 7 )}$ \\
SGROW & $0.0244^{*}$ & 0.0208 \\
& $(0.0137)$ & $(0.0135)$ \\
LEV & -0.00661 & 0.0125 \\
& $(0.0230)$ & $(0.0260)$ \\
DECLINE_1 & -0.00253 & -0.00139 \\
& $(0.00181)$ & $(0.00199)$ \\
LOSS_1 & $0.0454^{* * *}$ & \\
DECLINE_2 & $(0.00596)$ & \\
LOSS_2 & $0.0587^{* * * *}$ & \\
& $(0.0111)$ & $0.0486^{* * *}$ \\
Constant & & $(0.00613)$ \\
Firm fixed effects & & $0.0764 * * *$ \\
Time dummies & & $(0.0143)$ \\
Observations & 1.189 & 0.919 \\
R-squared & $(1.219)$ & $(0.941)$ \\
F & YES & YES \\
& YES & 662 \\
\end{tabular}

Notes: This table presents FE regression estimates for the pooled dataset for 229 targets and three-year event period, in particular the Year $0,-1$ and -2 (the three years preceding the takeover). The dependent variables are discretionary current accruals estimated using cross-sectional modified Jones model (ab_wcacc_mjcf) and discretionary current accruals estimated using cross-sectional performance-adjusted model (ab_wcacc_pmcf) in all these models. 1/ HERF is the reciprocal of the Herfindahl index for industrial diversification for each firm year (based on two-digit SIC code as reported by Worldscope database). SIZE represents the natural log of market capitalisation. $S G R O W$ is sales growth ratio. The $L E V$ ratio is total debt to total equity. DECLINE_l is a dummy variable which equals 1 if there is any decline in premanaged earnings (computed on the basis of discretionary current accruals estimated using cross-sectional modified Jones model) from those of the previous year, and 0 otherwise. DECLINE_2 is a dummy variable which equals 1 if there is any decline in pre-managed earnings (computed on the basis of discretionary current accruals estimated using the cross-sectional performance-adjusted Model) from those of the previous year, and 0 otherwise. $L O S S_{-} 1$ is a dummy variable which equals 1 if premanaged earnings (computed on the basis of discretionary current accruals estimated using cross-sectional modified Jones model) are negative, and 0 otherwise. LOSS_2 is a dummy variable which equals 1 if pre-managed earnings (computed on the basis of discretionary current accruals estimated using the cross-sectional performance-adjusted Model) are negative, and 0 otherwise. All the models include an intercept and firmfixed effects. Time dummies are also included within these two regression models to control for differences in economic conditions throughout our study period (1990-2008). The value of cluster-robust standard errors is in brackets. ***, **, * indicate that the parameter estimate is significantly different from zero at the $1 \%, 5 \%$ or $10 \%$ level, respectively. 


\section{Discussion and Conclusions}

This paper investigates whether earnings management is facilitated or mitigated by corporate diversification for a sample of 229 UK publicly listed target firms between 1990 and 2008. We follow the literature (Jiraporn et al., 2008; El Mehdi and Seboui, 2011) and report on industrial diversification and geographic diversification. The empirical evidence derived both from a cross-sectional analysis based on the modified-Jones model and the performance-adjusted model, and a FE regression analysis shows that industrial diversification mitigates earnings management by UK targets prior to M\&As and geographic diversification does not contribute to a higher magnitude of earnings management. In addition, the results of our study also show that a combination of industrial and geographic diversification alleviates earnings management.

Our results provide added detail and clarity to whether industrial and geographic diversification are related to increased levels of earnings management. We separated industrial and geographic diversification to test the potential different impact of the different strategies. Firstly, we found that, in comparison with single-segment firms, industrially diversified firms have a lower degree of earnings management, regardless of whether they operate only domestically or across different geographic regions. This provides empirical support to our hypothesis that in companies, even if attempted, using accruals to manipulate earnings' results would be difficult, because of the variability across the segment. To note, our analysis did not rule out the possibility that a heightened incentive to manipulate earnings may exist in industrially diversified firms, but just that there is statistically significant evidence that such attempts are made less frequently. Our findings support results from Jiraporn et al. (2008) and El Mehdi and Seboui (2011). Furthermore, our results support the view that industrially diversified firms do not suffer more severe information asymmetry (Thomas, 2002). Secondly, we examined usage of accruals earnings manipulation in domestic firms and geographically-diversified firms, regardless of whether they operate in one or many industries. In this case we found that geographic diversification is associated with a higher degree of earnings management, however the results are not statistically significant. Our findings are consistent with those reported by Chin et al. (2009). Our results point to the conclusion that industrial diversification is associated with lower rate of occurrences of earnings management, but geographic diversification is not. We see as a fruitful avenue for future research examinations of cases of positive identified earnings' manipulations (perhaps 
through the use of court cases), in single-segment and industrially-diversified firms and study the impact of such attempts on the firms. 


\section{Appendix A: Discretionary Accruals Definitions}

We define current accruals following Botsari and Meeks (2008):

\section{Working Capital Accruals from the Balance Sheet}

Working (current) capital accruals are defined as the change in non-cash current assets (CA) minus the change in current liabilities (CL) (no adjustment is made for the current portion of long-term debt). The codes for the Worldscope items are as follows:

$[\Delta \mathrm{CA}(W C 02201)-\Delta \operatorname{Cash}($ WC02001) $]-\Delta \mathrm{CL}(W C 03101)$

\section{Working Capital Accruals from the Cash Flow Statement}

Working (current) capital accruals are defined are the difference between net income before extraordinary items (NI) (as reported in the cash flow statement) ${ }^{23}$ and operating cash flow $(\mathrm{CFO})^{24}$ (excluding depreciation) (D\&A). The codes for the Worldscope items are as follows:

NI (WC04001) - CFO (WC04201+WC04831) - D\&A (WC04051).

\footnotetext{
${ }^{23}$ The same definition of net income less extraordinary items has been used by prior studies (e.g., Dechow et al., 2003; Kothari et al., 2005).

${ }^{24}$ Again, following Botsari and Meeks (2008), we calculate CFO as the sum of two Worldscope items, in particular, "Funds from Operations" (WC04201) and "Funds from/for Other Operations" (WC04831).
} 


\title{
Appendix B: Sample Selection Process and Reconciliation of the Initial and Final Sample of Targets
}

\author{
Table 1 Sample Construction: 229 UK-listed Targets Involved in M\&As \\ between 1 January, 1990 and 31 December, 2008
}

1. - targets involved in deals where the percentage owned by acquirer after the acquisition was equal to or higher than $50 \%$ were identified;

- 911 were deleted;

2. $\quad$ - $\quad 1024$ successful M\&As were identified ${ }^{25}$;

- the remaining 1238 uncompleted deals were cross-checked with the Fame/Zephyr database, ${ }^{26}$ another 41 of these were identified as completed deals and added back to the sample;

- 1197 deals were deleted;

3. - the listing status of targets was checked and 940 publicly listed targets involved in completed M\&As were identified;

- $\quad$ an additional 25 publicly listed targets were found using alternative sources of information;

- data regarding the listing status of 66 target firms were collected manually from Datastream/Worldscope and Fame/Zephyr databases;

- a further 100 were deleted;

4. $\quad$ - 51 special M\&As, such as financial acquirer, acquirer is a white knight, liquidation deals and bankruptcy acquisitions, were deleted from the sample;

a further 183 special deals, such as restructuring, three-way merger, collar, reverse takeover, scheme of arrangement, divestiture and privately-negotiated purchase were deleted from the sample;

6. $\quad$ - of the 731 targets involved only in Tender Offer/Tender Merger deals (classified by TOB M\&A database) ${ }^{27}$, an additional 112 financials (SIC Codes 60-69) were excluded from the previous sample; ${ }^{28}$

7. - the location of the stock exchange where the target's shares had been traded was checked and 27 cross-listing and non-London Stock-Exchange (LSE) targets were identified;

- a further 27 were deleted, which resulted in a sample of 592 LSE targets;

- financial information for each target in the sample was obtained from the Datastream/Worldscope database, therefore the Datastream/Worldscope codes were necessary to get financial information for the 433 targets in the sample;

- $\quad$ there were 159 targets with unavailable Datastream/Worldscope codes;

- the Datastream/Worldscope data were then crossed-checked with the LSE website, the Nexis/Lexis academic database $\mathrm{e}^{29}$ and the TOB, and the Datastream/Worldscope codes for an additional 40 targets with unavailable codes on the TOB M\&A database were found; a further 119 targets were deleted;

\footnotetext{
${ }^{25}$ According to the TOB M\&A database, all transactions are classified in terms of the status of transaction as completed, rumoured, intended, pending, unconditional, withdrawn and unknown status.

${ }^{26}$ The Fame/Zephyr database provides a comprehensive listing of UK deals, offering not only deal-specific but detailed accounting information (including listing status information) on public and private firms in the UK and Ireland. However, its coverage is only from 2001 onwards.

${ }^{27}$ According to the TOB M\&A database, a Tender Offer is defined as a formal offer of determined duration to acquire a public company's shares made to equity holders; the offer is often conditioned upon certain requirements, such as a minimum number of shares being tendered. Tender/Merger is the case where a tender offer is launched to acquire control of a company, and the offer is followed by a merger agreement in which the acquirer agrees to purchase the remaining shares not tendered under offer.

${ }^{28}$ Only non-financial targets were selected as the accrual process of financial companies is different than that of industrial firms, and comparability could not be ensured if they were kept within the sample. In addition, financial companies face more disclosure requirements as they are closely regulated, so their ability to manage earnings is lower than that of non-financial companies (Louis, 2004).

${ }_{29}^{29}$ The Nexis/Lexis academic database contains company profiles and identifying codes, M\&A news and LSE announcements on UK companies.
} 
8. the financial statement data for a minimum two consecutive years could not be obtained for 57 targets, which were, therefore, excluded;

9. $\quad-\quad 22$ companies with abnormal financial statement figures, such as zero cash and sales ${ }^{30}$ were identified and were deleted;

- the financial statement data for at least 4 consecutive years prior to the deal were necessary to estimate discretionary accruals, 98 companies with a financial history lower than 4 years were identified and deleted;

10. - outliers in raw data on all variables used to calculate accruals were eliminated by trimming the sample at $1 \%$ and $99 \%$; therefore; thus, 6 companies with extreme values were deleted

11. - 33 targets which were listed on the Alternative Investment Market (AIM) were identified and were deleted;

12. - segmental data for each target were obtained from the Worldscope database over the period 1990-2008;

- missing data on industry segments for 23 firms and data on geographic segments for 8 firms were collected manually from the Nexis/Lexis database;

- the remaining 27 firms with missing segmental data were deleted;

- 1 firm with a HERF value higher than 1 was deleted, leaving 229 targets in the sample

Total firms for target sample

Notes: This table presents the sample selection process and reconciles the initial and final samples of targets.

${ }^{30}$ A company with zero cash and sales is considered to be a shelf or shell company in the literature, therefore if they were kept in the sample, their extremely low level of operational activity would have led to biased accruals results. 


\section{REFERENCES}

Aleksanyan, M., \& Danbolt, J. (2012). Segment Reporting in the UK. Available at SSRN: http://dx.doi.org/10.2139/ssrn.2180894.

Alves, P., Beekes, W., \& Young, S. (2007). A comparison of UK firms' financial statement data from six sources: Working Paper. University of Lancaster.

Anagnostopoulou, S. C., \& Tsekrekos, A. E. (2012). Earnings management in firms seeking to be acquired. Proceedings of the 35th Annual Congress of the European Accounting Association (EAA), Ljubljana, Slovenia.

Anagnostopoulou, S. C., \& Tsekrekos, A. E. (2013). Do firms that wish to be acquired manage their earnings? Evidence from major European countries. International Review of Financial Analysis, 30 (December 2013), 57-68.

Anilowski, C., Macias, A. J., \& Sanchez, J. M. (2014). The Mediating Effects of Deal Initiation and Method of Sale in Acquisitions. Available at SSRN: http://dx.doi.org/10.2139/ssrn.1339963.

Antoniou, A., Arbour, P., \& Zhao, H. (2008). How much is too much: Are merger premiums too high? European Financial Management, 14(2), 268-287.

Armstrong, C. S., Barth, M. E., Jagolinzer, A. D., \& Riedl, E. J. (2010). Market reaction to the adoption of IFRS in Europe. The Accounting Review, 85(1), 31-61.

Ataullah, A., Davidson, I., Le, H., \& Wood, G. (2014). Corporate diversification, information asymmetry and insider trading. British Journal of Management, 25(2), 228-251.

Ball, R., \& Shivakumar, L. (2008). Earnings quality at initial public offerings. Journal of Accounting and Economics, 45(2-3), 324-349.

Barth, M. E., Landsman, W. R., \& Lang, M. H. (2008). International accounting standards and accounting quality. Journal of Accounting Research, 46(3), 467-498.

Barton, J., \& Simko, P. J. (2002). The balance sheet as an earnings management constraint. The Accounting Review, 77(Supplement 2002), 1-27.

Beattie, V., Goodacre, A., \& Fearnley, S. (2003). And then there were four: A study of UK audit market concentration-causes, consequences and the scope for market adjustment. Journal of Financial Regulation and Compliance, 11(3), 250-265.

Beneish, M. D. (1998). Discussion of "Are accruals during initial public offerings opportunistic?". Review of Accounting Studies, 3(1), 209-221.

Berger, P. G., \& Ofek, E. (1995). Diversification's effect on firm value. Journal of Financial Economics, 37(1), 39-65. 
Bertrand, O., \& Zitouna, H. (2008). Domestic versus cross-border acquisitions: Which impact on the target firms' performance? Applied Economics, 40(17), 2221-2238.

Bodnar, G. M., Tang, C., \& Weintrop, J. (1997). Both sides of corporate diversification: The value impacts of geographic and industrial diversification: Working Paper. National Bureau of Economic Research.

Boone, A. L., \& Mulherin, J. H. (2007). How are firms sold? The Journal of Finance, 62(2), 847-875.

Botsari, A., \& Meeks, G. (2008). Do Acquirers Manage Earnings Prior to a Share for Share Bid?. Journal of Business Finance and Accounting, 35(5/6), 633-670.

Braga-Alves, M. V., Ellis, J., Mandelker, G. N., \& Zutter, C. J. (2010). The effect of takeover probability on earnings management: Working Paper. Marquette University.

Burgstahler, D., \& Dichev, I. (1997). Earnings management to avoid earnings decreases and losses. Journal of Accounting and Economics, 24(1), 99-126.

Cahan, S. F., Rahman, A., \& Perera, H. (2005). Global diversification and corporate disclosure. Journal of International Accounting Research, 4(1), 73-93.

Cameron, A. C., \& Trivedi, P. K. (2010). Microeconometrics using stata (Revised ed.). Texas: Stata Press (Chapter 8).

Chin, C.-L., Chen, Y.-J., \& Hsieh, T.-J. (2009). International diversification, ownership structure, legal origin, and earnings management: Evidence from Taiwan. Journal of Accounting, Auditing \& Finance, 24(2), 233-262.

Choy, H. L. (2012). Assessing earnings management flexibility. Review of Accounting and Finance, 11(4), 340-376.

Cohen, D. A., \& Zarowin, P. (2010). Accrual-based and real earnings management activities around seasoned equity offerings. Journal of Accounting and Economics, 50(1), 2-19.

Comment, R., \& Jarrell, G. A. (1995). Corporate focus and stock returns. Journal of Financial Economics, 37(1), 67-87.

Dechow, P. M. (1994). Accounting earnings and cash flows as measures of firm performance: The role of accounting accruals. Journal of Accounting and Economics, 18(1), 3-42.

Dechow, P. M., Richardson, S. A., \& Tuna, I. (2003). Why are earnings kinky? An examination of the earnings management explanation. Review of Accounting Studies, $8(2-3), 355-384$.

Dechow, P. M., Sloan, R. G., \& Sweeney, A. P. (1995). Detecting Earnings Management. The Accounting Review, 70(2), 193-225. 
DeFond, M. L., \& Jiambalvo, J. (1994). Debt covenant violation and manipulation of accruals. Journal of Accounting and Economics, 17(1/2), 145-176.

Denis, D. J., Denis, D. K., \& Sarin, A. (1997). Agency problems, equity ownership, and corporate diversification. The Journal of Finance, 52(1), 135-160.

Denis, D. J., Denis, D. K., \& Yost, K. (2002). Global diversification, industrial diversification, and firm value. The Journal of Finance, 57(5), 1951-1979.

Doyle, J.T., Ge, W., \& McVay, S. (2007). Accruals quality and internal control over financial reporting. The Accounting Review, 82(5), 1141-1170.

Duru, A., \& Reeb, D. M. (2002). International diversification and analysts' forecast accuracy and bias. The Accounting Review, 77(2), 415-433.

Dye, R. A. (1988). Earnings management in an overlapping generations model. Journal of Accounting Research, 26(2) 195-235.

Easterwood, C. M. (1997). Takeovers And Incentives For Earnings Management: An Empirical Analysis. Journal of Applied Business Research, 14(1), 29.

Eddey, P. H., \& Taylor, S. L. (1999). Directors' Recommendations on Takeover Bids and the Management of Earnings: Evidence from Australian Takeovers. Abacus, 35(1), 29-45.

El Mehdi, I. K., \& Seboui, S. (2011). Corporate diversification and earnings management. Review of Accounting and Finance, 10(2), 176-196.

Erickson, M., \& Wang, S. M. (1999). Earnings management by acquiring firms in stock for stock mergers. Journal of Accounting and Economics, 27(2), 149-176.

Ewert, R., \& Wagenhofer, A. (2005). Economic effects of tightening accounting standards to restrict earnings management. The Accounting Review, 80(4), 1101-1124.

Farooqi, J., Harris, O., \& Ngo, T. (2014). Corporate diversification, real activities manipulation, and firm value. Journal of Multinational Financial Management, 27, 130-151.

Gande, A., Schenzler, C., \& Senbet, L. W. (2009). Valuation effects of global diversification. Journal of International Business Studies, 40(9), 1515-1532.

Gertner, R. H., Scharfstein, D. S., \& Stein, J. C. (1994). Internal versus external capital markets: Working Paper. National Bureau of Economic Research.

Graham, J. R., Harvey, C. R., \& Rajgopal, S. (2005). The economic implications of corporate financial reporting. Journal of Accounting and Economics, 40(1-3), 3-73.

Hartzell, J. C., Ofek, E., \& Yermack, D. (2004). What's in it for me? CEOs whose firms are acquired. The Review of Financial Studies, 17(1), 37-61. 
Hribar, P., \& Collins, D. W. (2002). Errors in Estimating Accruals: Implications for Empirical Research. Journal of Accounting Research, 40(1), 105-134.

Jiraporn, P., Kim, Y. S., \& Mathur, I. (2008). Does corporate diversification exacerbate or mitigate earnings management?: An empirical analysis. International Review of Financial Analysis, 17(5), 1087-1109.

Kasznik, R. (1999). On the association between voluntary disclosure and earnings management. Journal of Accounting Research, 37(1), 57-81.

Kim, Y. S., \& Mathur, I. (2008). The impact of geographic diversification on firm performance. International Review of Financial Analysis, 17(4), 747-766.

Kothari, S. P., Leone, A. J., \& Wasley, C. E. (2005). Performance matched discretionary accrual measures. Journal of Accounting and Economics, 39(1), 163-197.

Lang, L. H. P., \& Stulz, R. M. (1994). Tobin's q, Corporate Diversification, and Firm Performance. Journal of Political Economy, 102(6), 1248-1280.

Lim, C. Y., Thong, T. Y., \& Ding, D. K. (2008). Firm diversification and earnings management: evidence from seasoned equity offerings. Review of Quantitative Finance and Accounting, 30(1), 69-92.

Liu, Y., Taffler, R., \& John, K. (2009). CEO value destruction in M\&A deals and beyond: Working Paper. University of Edinburgh Business School.

Louis, H. (2004). Earnings management and the market performance of acquiring firms. Journal of Financial Economics, 74(1), 121-148.

McNichols, M. F. (2000). Research design issues in earnings management studies.Journal of Accounting and Public Policy, 19(4-5), 313-345.

Moeller, S. B., Schlingemann, F. P., \& Stulz, R. M. (2004). Firm size and the gains from acquisitions. Journal of Financial Economics, 73(2), 201-228.

Nam, J., Tang, C., Thornton, J. H., \& Wynne, K. (2006). The effect of agency costs on the value of single-segment and multi-segment firms. Journal of Corporate Finance, 12(4), 761-782.

Nichols, N. B, \& Street, D. L. (2007). The relationship between competition and business segment reporting decisions under the management approach of IAS 14 revised. Journal of International Accounting, Auditing and Taxation, 16(1), 51-68.

Raman, K., Shivakumar, L., \& Tamayo, A. (2013). Target's earnings quality and bidders' takeover decisions. Review of Accounting Studies, 18(4), 1050-1087.

Rangan, S. (1998). Earnings management and the performance of seasoned equity offerings. Journal of Financial Economics, 50(1), 101-122. 
Richardson, V. J. (2000). Information asymmetry and earnings management: Some evidence. Review of Quantitative Finance and Accounting, 15(4), 325-347.

Rodríguez-Pérez, G., \& Van Hemmen, S. (2010). Debt, diversification and earnings management. Journal of Accounting and Public Policy, 29(2), 138-159.

Rossi, S., \& Volpin, P. F. (2004). Cross-country determinants of mergers and acquisitions. Journal of Financial Economics, 74(2), 277-304.

Roychowdhury, S., Kothari, S.P., \& Mizik, N. (2012). Managing for the moment: The role of earnings management via real activities versus accruals in SEO valuation. The Accounting Review, Forthcoming. Available at SSRN: http://dx.doi.org/10.2139/ssrn.1982826.

Seetharaman, A., Gul, F. A., \& Lynn, S. G. (2002). Litigation risk and audit fees: Evidence from UK firms cross-listed on US markets. Journal of Accounting and Economics, 33(1), 91-115.

Shen, M. (2005). Earnings management incentives of target firms: an analysis of soliciting and unsolicted targets'accrual accounting choices. PhD Dissertation. Michigan State University.

Shleifer, A., \& Vishny, R. W. (2003). Stock market driven acquisitions. Journal of Financial Economics, 70(3), 295-311.

Skaife, H. A., \& Wangerin, D. D. (2013). Target financial reporting quality and M\&A deals that go bust. Contemporary Accounting Research, 30(2), 719-749.

Sloan, R. G. (1996). Do stock prices fully reflect information in accruals and cash flows about future earnings? The Accounting Review, 71(3), 289-315.

Stein, J. C. (1997). Internal capital markets and the competition for corporate resources. The Journal of Finance, 52(1), 111-133.

Subramanyam, K.R. (1996). The pricing of discretionary accruals. Journal of Accounting and Economics, 22(1), 249-281.

Teoh, S. H., Welch, I., \& Wong, T. J. (1998). Earnings management and the underperformance of seasoned equity offerings. Journal of Financial Economics, 50(1), 63-99.

Thomas, S. (2002). Firm diversification and asymmetric information: evidence from analysts' forecasts and earnings announcements. Journal of Financial Economics, 64(3), 373396.

Thomas, W. B. (1999). A test of the market's mispricing of domestic and foreign earnings. Journal of Accounting and Economics, 28(3), 243-267. 
Trueman, B., \& Titman, S. (1988). An explanation for accounting income smoothing. Journal of Accounting Research, 26( Supplement 1988) 127-139.

Wooldridge, J. M. (2002). Econometric analysis of cross section and panel data: Cambridge, The MIT press (Chapter 10).

Zang, Aa. Y. (2011). Evidence on the trade-off between real activities manipulation and accrual-based earnings management. The Accounting Review, 87(2), 675-703. 